for the operation and maintenance of the reactor. The reactor will be built on the site of the National Engineering Laboratory at East Kilbride, near Glasgow. The main part of the scientific programme will be the production of short-lived radio isotopes for research in chemistry, metallurgy, biology and medicine. The reactor will also provide teaching and training facilities for engineers and physicists in reactor technology.

\section{British Space Research}

IN replying for the Government in a debate in the House of Lords on space research on December 6, which was notable for the high level of its speeches, the Minister for Science, Lord Hailsham, commented that the present organization for space research in Britain was devised by him just over two years ago when the Scout satellite programme began. He said he regards the present organization as an interim device, but belioves it should continue until the future plans are better known. The current programme this year will extend to 15-20 firings of the Skybolt rocket, 10 of which will carry experiments selected under the xois of the Royal Society from proposals made by research workers in universities and Government Departments, and dealing with all aspects of the physics of the upper atmosphere and studies of the Sun and stars. Six will be simple rounds carrying grenades for meteorological observations under a Royal Society programme. The university experiments are financed by grants from the Department of Scientific and Industrial Research, and the manufacture of the rockets has been undertaken by the Ministry of Aviation. The launching and collection of data are a joint Anglo-Australian responsibility.

Lord Hailsham claimed that the British programme of sounding rockets has already produced important information about the atmosphere and the ionosphere, and has had direct effects on such areas of applied science as radio research and meteorology, and there has been no duplication of effort. The experiments on the Scout programme are boing financed by Department of Scientific and Industrial Research grants at a rate of about $£ 160,000$ a year on the advice of the Royal Society, and substantial sums are also being spent on similar experimental work in Government research establishments, particularly the Radio Research Station. The launching of the first of these by the Delta rocket, a threo-stage liquid-fuelled rocket, is scheduled for next spring. The Government is also giving full support to the European Space Research Organization, which will provide a framework for scientific co-operation, and to the European Launcher Development Organization, proposals for which provide for an initial programme of about $£ 70$ million over five years for the development and construction of a launcher, using Blue Streak as the first stage, a French rocket as the second, and a third stage to be developed under the leadership of Germany. In parallol with investigations made by the British Space Development Co., studies of a possible design of a communication satellite programme have been made jointly by the Post Office and the Ministry of Aviation. Lord Hailsham said that to ignore space research would be to opt out of most exciting developments in physics, astronomy, the earth sciences, engineering and technology; but he reaffirmod that British participation must be governed not by considerations of prestige but by matter of fact regard to resources available and scientific advantages.

\section{Communications Satellites}

Tre ground radio station at Goonhilly Downs, on the Lizard, Cornwall, is being built by the General Post Office in order to carry out experiments in satellite communications. The Post Office is cooperating with the U.S. National Aeronautics and Space Administration in a programme for transAtlantic testing of communications satellites. Other countries, including France and the Federal Republic of Germany, are also to co-operate in the tests. The British ground station, which will cost about $£ 750,000$, will be used for the reception and transmission of telephone, telegraph and television signals across the Atlantic, using satellites to be launched by the National Aeronautics and Space Administration, commencing in 1962, known as Projects Relay and Telstar. Both projects involve the active use of satellites launched in elliptical orbits with a maximum height of about 3,000 miles, inclined at about $50^{\circ}$ to the equator. The Project Relay satellite is being designed and built by the Radio Corporation of America, and the Project Telstar satellite by the Bell Telephone Laboratories. The United States ground station is being built at Rumford, Maine, by the American Telephone and Telegraph Co. and the associated Bell Telephone Laboratories. The Post Office ground station is being equipped with radio facilities of an advanced type, including an 85-ft. diameter steerable aerial capable of being pointed automatically and with great precision in the direction of the satellite.

Projects Relay and Telstar are essentially research and dovelopment projects to demonstrate the technical feasibility of satellite communications and to provide data on which the design of operational systems could ultimately be based. The Post Office, in co-operation with the Ministry of Aviation, has carried out studies of the problems associated with communications satellite systems, with the following objectives: (i) continuous 24-hr. service for telephony and telegraphy between all ground stations provided in connexion with the system; (ii) world-wide coverage in association with the existing cable and radio links; (iii) provision for the satellites to carry about 1,000 telephone channels and a television channel; (iv) the system should be capable of co-operating with some twenty or thirty ground stations in various parts of the world without requiring more than two satellite links in tandem. In general, the number of satellites required in a system depends on the type of orbit adopted and its height, or whether the satellites are controlled in position in this orbit or are randomly distributed, and to some extent on the number and location of the ground stations. For example, with satellites controlled in position in an equatorial orbit, twelve satellites would need to be put into orbit at a hoight of about 7,500 nautical miles to meet the objectives. The information and experience that will be gainod from the North Atlantic tests in 1962 should be of great value in future planning.

\section{Radio Astronomy Planning Committee in Britain}

The Minister for Science, Lord Hailsham, has set up a Radio Astronomy Planning Committeo. The precise terms of reference are: "To consider and advise on the nature and extent of the participation 